\title{
STUDIES IN OBERONIA, 9: LESSONS FROM EXCESS NAMES IN OBERONIA FOR ORCHIDACEAE SYSTEMATICS, INCLUDING A REVISION OF THE OBERONIA SECT. SCYTOXIPHIUM
}

\begin{abstract}
Daniel L. Geiger
Santa Barbara Museum of Natural History, 2559 Puesta del Sol, Santa Barbara, CA 93105, USA; Visiting Research Scholar, Huntington Library, Art, Museum and Botanical Gardens Botany Division, 1151 Oxford Street, San Marino, California 91108, USA.

dgeiger@sbnature2.org

ABSTRACT. The reasons for excess names in microfloral orchids such as Oberonia Lindl. can be traced to poor scholarship (e.g., failure to review the literature, ignoring expert advice), typological thinking, and erroneous assumption of microendemism. Some extraordinarily poor descriptions, including some from the $21^{\text {st }}$ century, can be termed "taxonomic vandalism". The outdated reliance on drawings as opposed to z-stacked photographs and scanning electron micrographs poses further problems due to an abundance of demonstrable problems with drawings. The Oberonia sect. Scytoxiphium Schltr. with eight described species is reduced to one species, Oberonia heliophila Rchb.f.; it is illustrated by original drawings, live photographs and scanning electron microscope images. The distribution is extended from Java through Micronesia and Samoa. The species occurs predominantly from $0-500 \mathrm{~m}$, less frequently to $900 \mathrm{~m}$, and possibly to even $1900 \mathrm{~m}$. It flowers throughout the year.
\end{abstract}

Keywords/Palabras clave: Oberonia, Oberonia sect. Scytoxiphium, revision, revisión, synonymies, sinonimias, taxonomic vandalism, vandalismo taxonómico

Introduction. Oberonia Lindl. is a genus of malaxid orchids with some 470 published species, of which some 200-300 have been considered to be correct by various authors over the past $190+$ years. That number has dropped recently by identifying at least 60 new synonyms (Geiger 2016, 2019, 2020a, Geiger et al. in press, Bunpha et al.2019), but more excess names need to be formally removed (Geiger unpubl. data). It appears that the presumed diversity of Oberonia has been overestimated by approximately one third. The degree of overnaming in the genus is astounding. Previous work on minute organisms such as the marine microsnail family Scissurellidae s.l. (Geiger 2012 and references therein) with a similar number of specieslevel names had fewer unrecognized synonyms, but over 60 genuinely new species (and even genera). The question arises, why do microfloral orchids still contain so many unrecognized synonyms?

Here I try to provide some explanations, which may serve other orchid systematists as an incentive to critically assess already described orchid diversity, to encourage to formally synonymize excess names, and not to contribute to the problem by describing even more taxa that ultimately prove to be synonyms. The last aspect, akin to the medical maxim of "do no harm" should apply to orchid systematics. The importance of alpha taxonomic assessment was recently stressed by Karremans et al. (2020) in their landmark contribution on Vanilla Plum. ex Mill.

Taxonomic vandalism.- It is remarkable that most of the names of Oberonia introduced in the later $20^{\text {th }}$ and $21^{\text {st }}$ century turn out to be synonyms of previously described species. In some cases, the descriptions are so poor in terms of lack of elementary scholarship that they qualify as "taxonomic vandalism" (see also Moore et al. 2014, Páll-Gergeley et al. 2020, Geiger 2020a). This term may sound like hyperbole, but examining the definition of vandalism as "willful or ignorant destruction of artistic or literary treasures" (Random House Dictionary of the English Language 1973) or "any activity that is considered to be damaging or destroying something that was good" (Cambridge Dictionary) shows that the term is appropriate in some cases.

In academic publishing, review of the existing literature is a key element of any contribution. If an author did not cite a single reference or missed a well-known 
and key reference, and thereby introduced superfluous names instead of using a good, correct name, it fits the definition of vandalism. The first situation is found in Chen's (2003) description of Hippeophyllum micrathum S.C.Chen, a synonym of Oberonia rhizomatosa J.J.Sm. (Geiger 2020a), with not a single reference cited. The second case is exemplified by George et al. (2019) who did not cite Ansari and Balakrishnan (1990) as the key review of Indian Oberonia in their description of O. saintberchmansii Kad.V.George \& J.Mathew, which would have immediately identified their specimen as O. brunoniana Wight (Geiger 2020a).

A second category is willful ignorance of expert advice. The present author communicated the identity of a specimen as $O$. griffithiana Lindl. That specimen was described anyway as $O$. khuongii Aver. \& V.C.Nguyen (Averyanov et al. 2019). The new species was compared to a very dissimilar species $(O$. cavaleriei Finet), but $O$. griffithiana was only mentioned in passing and no differentiating characters were given. The protologue of $O$. griffithiana is easily available on-line from the Biodiversity Heritage Library, and the illustrations are exquisite. The two species were synonymized formally by Geiger (2020a).

Explanatory taxonomy. - If we subscribe to the premise that systematics as a branch of the natural sciences is explanatory (e.g., Popper 1983, Josephson \& Josephson 1993), and the simplest explanation is the best (Ockham's Razor, Mach's Principle of Economy, parsimony), it follows that the goal of systematics should be to explain biodiversity by postulating the fewest species. The term parsimony is used here in the broad philosophical sense, as opposed to the more restricted meaning in phylogenetic systematics generally associated with Hennigian cladistics (Wiley et al. 1991). In cladistics, the phylogeny requiring the fewest character state changes, the most parsimonious tree, is the best evolutionary explanation for the characters observed. This is a special application of a general principle that the simplest explanation should be preferred, or the explanation requiring the fewest ad hoc assumptions. This guiding principle is so widely applied that it is known under several names including Ockham's razor and Mach's Principle of Economy.

van Steenis phrased the above: "It is not our task to find out how many species there are, but how few."
(P. Hovenkamp pers. comm.). This approach is also termed "lumping" as opposed to "splitting" in systematics. In a perfect world and as a normative goal, we strive to find out how many true species exist in the world. In the real world, though, there are borderline cases. Both, from the philosophical-economical explanation perspective, as well as following van Steenis' circumscription, it follows not to describe an additional species unless there is good evidence for it. From an explanatory and information criterion perspective, the postulation of a new species should be a measure of last resort. It should be viewed as an admission of failure to explain the observed specimen as an instance of already described species, applying the species-askind concept (Mahner \& Bunge 1997).

Such a restrained approach to describing species may surprise some readers, particularly in the light of habitat loss and the sixths mass extinction of the Anthropocene. Taxonomy is a pure science, not a branch of practical conservation biology. As taxonomists we evaluate specimens and place them in order to the best of our abilities. If an endangered species turns out to be the same as a widespread one, a responsible taxonomist will synonymize the two. The reduced number of endangered species is of no concern to a taxonomist. Similarly, math does not change its rules. One plus one still is two, even if three would look better to some as it is a larger number.

There is always the possibility that novel characters may justify additional taxa. That possibility should not be abused by wantonly introducing new species and leaving it to subsequent workers to find the characters. Every new species must be justified in its protologue.

Specimen/gathering vs. species.- An overlooked source of unrecognized synonyms is the confusion between specimen/gathering and species. This point may seem to be ill founded as every biologist is well aware of the distinction. However, problems arise from implicit assumptions.

To set the stage, some elementary clarification is required. A single specimen and even multi-specimen gatherings are generally presumed to contain one genotype of one species. Accordingly, a specimen/gathering is one instance of a species. Species are composed of multiple specimens/genotypes, exhibiting some natural variability, which serves the raw material on which 
selection acts; species may also show some variability due to phenotypic plasticity stemming from genotype $x$ environment interaction. The existence of variability is undoubted in biology, but it is hardly ever explicitly taken into account in species descriptions or comparisons. When natural variability is not considered, and the type specimen is taken as the immutable template of a species' morphology, this approach is referred to as typological thinking (Mayr 1994). Such practices are in stark contrast to the principles of systematics, where names are not given to specimens but to species, which are composed of multiple individuals making up at least one population. It is well understood that types are specimens by necessity, but they are only name bearers (semaphoronts) for the species, having some natural variability, that they define. Ideally, the name-bearing type (holotype, lectotype) exhibits near the average or typical form of the species, but there are many counter examples, while syntypes as well as isotypes and paratypes may document some variability of the species.

When comparing two species, the variability of both need to be considered. The assessment of variability is the domain of statistical analysis, both in terms of descriptive statistics (mean, mode, standard deviation, standard error, skewness, kurtosis) as well as in comparative statistics (t-test, chi square test, ANOVA, DFA). The principles of statistics can easily be applied to systematics.

The interrelation of sample size and smallest detectable significant difference is important to bear in mind. All other things being equal, with large samples, small significant differences can be detected. With small samples, the difference needs to be large to be demonstrably meaningful. Translated to systematics, for a species to be distinct, either a large sample size with consistent small differences is required, or the difference needs to be stark if only few specimens are available. Minute differences between few plants are more likely to represent intraspecific variability than species-level differences.

Assessments of single observations are a special case, because variance cannot be calculated from samples with $\mathrm{n}=1$. This case is treated in statistics as a t-test of a single value with a mean (Sokal \& Rohlf 1981). The variance of the single specimen is presumed to be the same as the one from a sample with multiple observations. Translated to botanical systematics, the variability of specimens from potentially new species, typically known from only limited material, needs to be presumed to be equal to that of a well-studied species with plenty of available material. When assessing species that both have only very limited material available (e.g., both only known from type), then the variance of both is presumed to be that of a reasonably close species. Species in the same genus, or section if well-defined, provide that information.

The practical application comes particularly when reading older diagnoses and comparisons, for instance by Schlechter, J. J. Smith, Ridley, or Gagnepain. Their descriptions were typically based on a single gathering, $\mathrm{n}=1$. If a comparison was provided, it was typically based on information from the protologue of other species also based on single gatherings, $\mathrm{n}=1$. However, a comparison of two species implicitly assumes and suggests that those differentiations are based on multiple specimens. That assumption is frequently mistaken, as the observational basis for all taxa is $n=1$. Accordingly, a comparison of specimens is carried out, masquerading as comparison of species. Intraspecific variability could not be taken into account and adducing known variance from other species was never done. Such descriptions should all a priori be considered to be synonyms, unless the difference is very pronounced. Schlechter (1911), however, in his treatment of Oberonia species frequently noted that the differentiation is difficult, which is an immediate red flag.

In my experience as a practicing systematist over 30 years, in instances where few specimens are at hand, it is easy to focus on small differences and to separate them into putative new species. As more and more material is examined, small differences evaporate and are correctly recognized as intraspecific variability or ontogenetic stages. I am not opposed to describing species, and even genera, based on small number of specimens, but they need to be strikingly different. Examples include Depressizona exorum Geiger (2003) and Severnsia strombiformis Geiger (2016) both introduced as a new genus and a new species based on four and two specimens, respectively (Geiger 2003 , 2016). They were both radically different from any other known genus or species.

Appropriate comparisons.- When describing a new species, comparison to the most similar taxa is criti- 
cal. A lack of any comparison is a first indication of a problem (e.g., Chen 2003). It is more difficult to notice meaningless comparisons in little-known groups. Authors frequently compare their supposed new species to ones that bear very little resemblance to them, instead of those that are much more similar. That comparison then suggests erroneously a large difference despite limited material, although, if the appropriate comparison would have been made, the differences would be much smaller, or even non-existent.

In order to be able to identify the most similar species, it is necessary to understand the species concept of every even remotely similar species, at a global level. This typically requires an understanding of every name ever applied in the genus. This is no small undertaking. After at least seven years of immersing myself in one genus, I still do not fully understand many species names in Oberonia. Authors describing new species in many groups, particularly those that have not been globally revised, are highly likely to introduce synonyms.

The above-mentioned case of $O$. khuongii is a case in point. The specimen has a common vegetative habit with flattened leaves on a moderately caulescent shoot. The only comparison was made to the acaulescent $O$. cavaleriei Finet with terete leaves, a character only found in two other species. There are multiple more appropriate comparisons, such as to $O$. rufilabris Lindl., $O$. insectifera Hook.f., $O$. jenkinsiana Griff. ex Lindl., and lastly also $O$. griffithiana Lindl., which is the correct name for $O$. khuongii. Those species all have flattened leaves.

Oberonia manipurensis Chowlu et al. (2015) with moderately fleshy long falcate leaves and subquadrate lip without distinct lateral lobes was compared to $O$. pachyphylla King and Pantl. with short, stubby and very fleshy leaves, and $O$. multidentata Aver. (=O. jenkinsiana Griff. ex Lindl.?) with distinct serrated lateral lobes, but not to O. mucronata (D.Don) Ormerod $\&$ Seidenf. or any of its synonyms, which it represents (Geiger 2019).

Oberonia saintberchmansii mentioned above having flowers with distinct lateral lobes and reflexed remaining tepals was only compared to $O$. falconer $i$ Hook.f. with a triangular lip without lateral lobes and spreading remaining tepals (section IV of Ansari \& Balakrishnan 1990), but not to any species in Ansari and Balakrishnan's (1990) section III with distinct lateral lobes and reflexed tepals (O. bruononiana Wight, $O$. chandrasekharanii V.J.Nair, V.S.Rachman \& R.Ansari, O. josephii C.J.Saldanha, O. nayarii R.Ansari \& N.P.Balakr., O. balakrishananii R.Ansari, O. platycaulon Wight, O. sebastiana B.V.Schetty \& Vivek., O. seidenfadeniana J.Joseph \& Vajr., O. wallichii Hook.f. $=O$. brunoniana, and $O$. wynadensis Sivad. \& R.T.Balakr.). This list of inappropriate comparisons could be extended significantly.

The number of instances of genuine disagreement on intraspecific variability vs. biodiversity is limited. One recent example is $O$. janae Aver. vs. O. pachyphylla King \& Pantl. Averyanov in Averyanov et al. (2015), which erroneously cited shared characters as differences (e.g., serration of bracts), and did not adduce known variability in other species to estimate variability. The case is discussed in more detail elsewhere (Geiger 2020a).

The geographic dispersal ability of species needs to be considered, and the list of potential species that need comparison adjusted accordingly. In the case of Oberonia, microendemism is highly unlikely given that they have the smallest seeds in the family Orchidaceae, and by extension, angiosperms. Average seed size is on the order of $150 \times 30 \mu \mathrm{m}$ (Barthlott et al. 2014, Geiger 2014, 2020a, Geiger unpubl. data, Geiger et al. 2020), hence, wind-dispersal will likely be extensive in these epiphytic species.

The term endemism is not well-defined in biology, as it is relative the geographic area it is compared to. All species are endemic to the planet earth. In general, an "endemic" species has a narrower distribution than one would expect based on comparison to closely related species. Microendemic species are even more restricted than one would expect. There are no hard rules on the cut-offs. As an arbitrary number, one could use less than $10 \%$ and $1 \%$ of range of a widespread species as a first approximation for those two terms. Frequently they are used with respect to a country such as Vietnam, i.e., a political entity, which has no biological relevance.

Some orchid species seem to have narrow distributions despite their small seeds. Such occurrences require additional explanation, such as host association, special niche requirements, or a combination of biotic and abiotic factors. The null hypothesis, though, has to 
include extensive dispersal abilities. Distribution is not a character of the species, and taxonomy only uses observations from the specimens. Any specimen should be able to be identified without knowing where it came from; two specimens that are indistinguishable except for provenance should be considered taxonomically identical, belonging to the same species.

A key problem in botany is the focus on geographically limited floras, rather than phylogenetic units. Species not known from a particular country are rarely considered in comparisons of new species descriptions. Imposing political boundaries on plants following phytogeographic patterns is untenable. With molecular techniques being applied, we can now confidently demonstrate extraordinarily wide distribution patterns in Oberonia, for instance from Malaya to French Polynesia (Geiger et al. 2020).

The drawback of drawings.- In botany, the standard for illustrations is usually still the line drawing. One perceived advantage is the easy juxtaposition of different parts of the plant at different scales. An overview of the entire plant is artfully integrated with an enlargement of the flower and other details. Such artistic composites can also be generated from images using current digital imaging technologies. In zoology, specimens $<5 \mathrm{~mm}$ have customarily been illustrated with z-stacked photographs or SEM images for at least the past 20 years as will be apparent from a quick perusal of publications in Zootaxa. It is not clear why botany has lagged behind in adopting $20^{\text {th }}$ and $21^{\text {st }}$ century imaging technologies.

On the other hand, and this is a rather specific issue with small objects, the detail that can be observed and rendered with a stereomicroscope is limited. For one, the extremely limited depth of field makes it difficult to recognize the overall structure in three dimensions. Some stereomicroscopes are equipped with a diaphragm to increase depth of field but closing the aperture will also reduce resolution due to diffraction. For scanning electron microscopy, depth of field, or more accurately depth of focus, is usually sufficient and stacking is not necessary. It can be increased with longer working distance with a slight loss in resolution. At the relatively low magnifications used, that reduced resolution is inconsequential. In variable pressure, the longer mean free path leads to signal attenua- tion, which can be compensated for with higher probe currents (100 vs. $500 \mathrm{pA})$. That large spot size is also inconsequential from the perspective of resolution at low magnification, but improves signal-to-noise ratio and, hence, image quality; see also Stokes (2008). Different detectors are more or less sensitive to changes in working distance in variable pressure. For instance, the Zeiss VPSE detector is more susceptible than the Zeiss C2DX detector (Geiger pers. obs.).

Light has intrinsic limitations with respect to potential resolution, which in practice is further limited by the optical system used. The theoretical resolution limit for light is half its wavelength $(\lambda / 2$ for $\lambda=$ $400-700 \mathrm{~nm} \sim 1 / 4 \mu \mathrm{m}$, Ray 2002). The limited numerical aperture (NA) particularly of stereomicroscopes, typically less than 0.1 , reduces the resolution limit to $>\sim 7 \mu \mathrm{m}(1.22 \times \lambda / \mathrm{NA}$ : range $4.9-8.5 \mu \mathrm{m})$. The SEM is limited by the probe size, typically $2-5 \mathrm{~nm}(=0.002-$ $0.005 \mu \mathrm{m})$, i.e., approximately $10^{3} \times$ better in linear dimension, $10^{6} \times$ in $2 \mathrm{D}$ area. At low magnifications, the number of pixels of the digital capture is the limiting factor. For an image 3000 pixels wide with a field of view of $2 \mathrm{~mm}$ (an entire Oberonia flower), each individual pixel represents approximately $0.7 \mu \mathrm{m}$. Even at low magnifications, the SEM has a better resolution by $\sim 10^{1} \times$ in linear dimension, by $\sim 10^{2} \times$ in $2 \mathrm{D}$ area. This level of detail is available to the investigator during the study, as the image can be displayed at full resolution on screen. Such an image shown in print approximately 3 " wide with a 150 lpi line screen can reveal details at a scale of $14 \mu \mathrm{m}$.

A further factor is the interrelationship of contrast and resolution, well-known from the modulation transfer function in light optics (Ray 2002). Low contrast features require lower spatial frequencies (= larger structures) than high contrast features to be discernable. Fine flower detail is typically low in contrast. It will increase the size of the smallest recognizable feature in light optical examination of flowers by an estimated factor of $5 \times \sim 35 \mu \mathrm{m}$. The SEM, on the other hand, accentuates edges due to effects of the electron beam and its interaction volume in the sample (Goldstein et al. 1992), hence, can display the full detail at the level of individual pixels. The SEM applies an unsharp mask filter to the image.

It is an open question of how much actual detail information is usually captured by a skilled scientific 

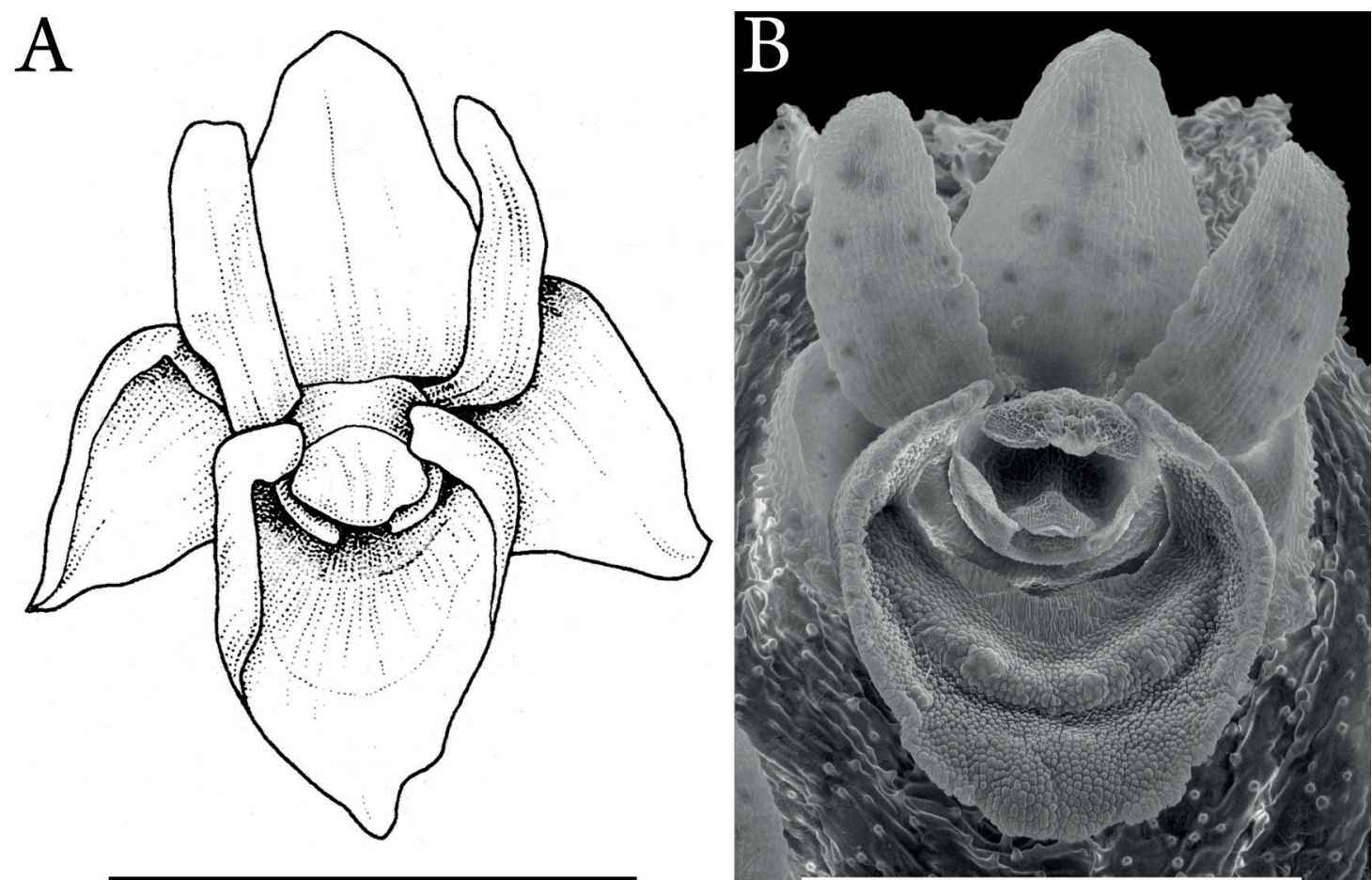

FiguRE 1. Comparison of botanical line drawing with SEM, Oberonia pachyrachis. A. Drawing from Seidenfaden (1978).

B. SEM image. Menzies \& Dupuy $192 \mathrm{~K} 47170$ from Thailand. Scale bars $=1 \mathrm{~mm}$.

illustrator, but it is very doubtful that the theoretical limit of the observation optics is transferred to the drawing. The above sample calculations were carried out at the low magnification end, and thus were least favorable to the SEM. At higher magnifications, the SEM's advantages become much more pronounced.

A comparison of a standard line drawing and an SEM image serves here as a case in point (Fig. 1). I have chosen the best line drawing available for $O$. pachyrachis Rchb.f. ex Hook.f. from a key work on Oberonia by the highly respected botanist Gunnar Seidenfaden. Seidenfaden's (1978: Fig. 3C; Fig. 1A here) illustration is compared to an SEM image (Fig. 1B). The line drawing shows the shape and proportions of the tepals well, but many details are not recognizable. The concentric dotted rings on the mesochile and epichile seem to allude to the distinct folded ridges revealed by the SEM. However, without the SEM image, it is impossible to understand the $3 \mathrm{D}$ folds based on the drawing. The short hairs on the back of the lateral sepals, clearly visible in the SEM, are not indicated in the line drawing. Most drawings in the literature of Oberonia do not attain the quality of Seidenfaden's illustration. They may be better referred to as sketches rather than drawings.

One argument in favor of line drawings is their inherent interpretative nature, and that specimen defects can be ameliorated to provide an idealized representation of the organism. However, this augmentation also has the potential for introducing unintended errors or suppressing details that may turn out to be significant in hindsight. Schlechter's $(1923,1934)$ drawings often show differences between the illustration of the entire flower and the individual floral elements. They may rather suggest intraspecific variability or show the appearance of the floral elements from different perspectives or may be drawing errors. For instance, the isolated lip of $O$. crassilabris Schltr. (Fig. 2H) shows distinct auricles, which are not shown in the drawing of the entire flower. Geiger (2019) discussed inconsistencies in the drawings of $O$. nayarii Ansari \& N.P.Balakr. and O. balakrishnanii Ansari in Ansari and Balakrishnan (1990). Inconsistencies in the drawings of $O$. ensiformis ( $\mathrm{Sm}$.) Lindl. flowers were discussed by Geiger (2020a). A particularly striking case is the drawing in the protologue of O. caprina Gilli (1983: fig. 29), which bears little resemblance to the holotype 
(W 16722 Gilli 164); see Geiger (2019) for details. Unfortunately, a bad drawing is not immediately recognizable as such; it must be taken at face value. On the other hand, deficiencies of photographs or SEM images are immediately apparent. This uncertainty factor surrounding drawings is a significant drawback.

Treatment in literature.- The treatment of species in the literature can be a further indication regarding the validity of the species. While there are genuinely rare species, if highly similar species are only treated by reference to the protologue with no new material, it raises questions. In some cases, voucher material can be helpful in untangling questionable species names.

For most early $20^{\text {th }}$ century synonyms, it is notable that they have hardly ever been cited after their introduction (e.g., O. vulcanica Schltr., O. nitida Seidenf.). Drawings are frequently copied and re-copied, while the discussions and comparisons are scant at best. It is assumed that every described species is correct. It may be better to treat every species epithet in a genus not clearly distinct from every species described before as a nomen dubium or nomen inquirendum (e.g., O. zimmermanniana J.J.Sm., O. werneri Schltr.).

The presumption of names to be correct may lead authors to focus on minute differences. Bunpha et al. (2019) distinguished $O$. denticulata Wight from $O$. gammiei King \& Pantl. by the shape of the rostellum and the position of a slight depression in the lip slightly above or below the middle of the lip. Neither illustrations to support their claims nor any indication on the number of specimens examined was provided. In the same article, however, $O$. nitida Seidenf. was correctly synonymized under $O$.denticulata, and $O$. falcata King $\&$ Pantl. was correctly synonymized under $O$. anthropophora Lindl. The latter pair shows extensive variability in the shape of the lip, for which reason it is unclear why Bunpha et al. (2019) elected to consider minute differences as significant in one species pair, but meaningless in others. Last but not least, these authors missed the senior synonym of $O$. denticulata, namely O. mucronata (D.Don) Ormerod \& Seidenf. as the correct name for both $O$. denticulata and $O$. gammiei.

The untenable distinction of $O$. fungum-olens Burkill from $O$. padangenesis Schltr. by Bunpha et al. (2019) correctly synonymized by Geiger (2019) was discussed elsewhere (Geiger et al. 2020).
Materials and methods. Taxonomic assessments were made based on available information from primary and secondary literature, herbarium holdings (B, BM, F, K, MEL, MICH, MO, P, SING, US, W), and on-line databases (HBG, L).

Illustrations were processed in AffinityPhoto. Z-stack photography was carried out on a Zeiss Discovery V20 stereomicroscope with planapochromatic lenses and motorized focus. Images stacks were captured with a Zeiss Axicocam HRc camera and processed in ZereneStacker. For scanning electron microscopy (SEM), flowers were preserved in 95\% ethanol, brought to $100 \%$ ethanol through three changes of $100 \%$ ethanol, critical point dried in a Tousimis $815 \mathrm{~A}$ using standard settings, then mounted on double sided carbon tabs (Ted Pella), sputter coated with gold, and imaged in a Zeiss EVO 40 XVP using the VPSE detector in variable pressure (30 Pa) at $20 \mathrm{kV}$ and probe currrents ranging from $30-500 \mathrm{pA}$ depending upon working distance and magnification.

\section{Section Scytoxiphium Schltr.}

TYPE: Oberonia crassilabris Schltr., subsequent designation by van Royen (1979: 711).

Remarks.- The section Scytoxiphium serves to illustrate some of the points made above. As the first sign of overnaming, Schlechter (1911: 176, translated from German) noted that "The establishment of boundaries of the species is difficult, because they are all closely related." Schlechter (1911) described in his new section $O$. pachyglossa and $O$. crassilabris from New Guinea and included $O$. dolichophylla Schltr. and O. rivularis Schltr. both previously described from New Guinea, $O$. heliophila Rchb.f. from Fiji, and O. betchei Schltr. from Samoa, but not $O$. asperula J.J.Sm. described previously from New Guinea (Smith 1908: see below).

Although Schlechter (1911: 176, translated from German) referred to "rich material of Scytoxiphium", the names were all introduced based on single gatherings ( $\mathrm{n}=1)$ except for O. dolichophylla based on two gatherings. It might well be that he used the term rich in the sense of number of species, as opposed to a large number of specimens. As the Berlin herbarium with all Schlechter's material was destroyed in World War II, it is impossible to verify either interpretation.

Schlechter (1911) compared his new species only to his own species from New Guinea. Although he 


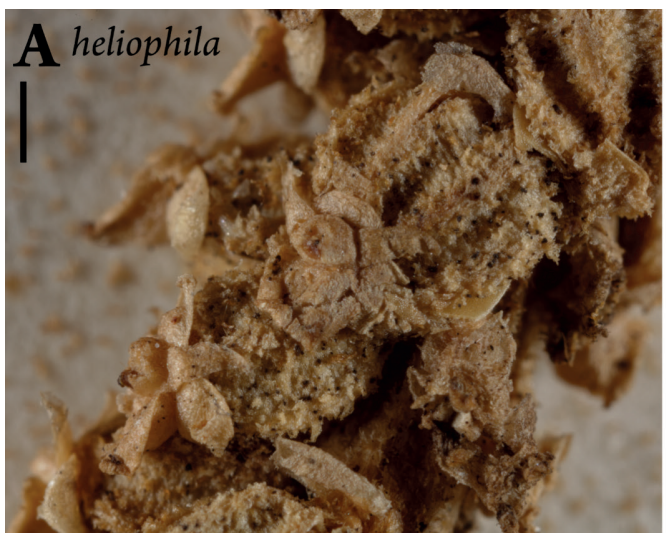

C rivularis

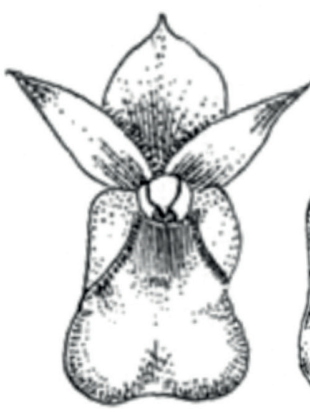

F dolichophylla

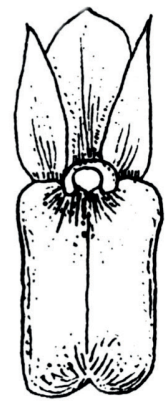

D inversiflora

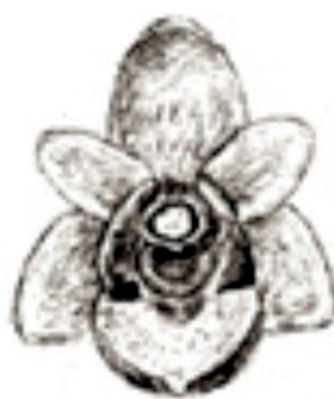

G pachyglossa

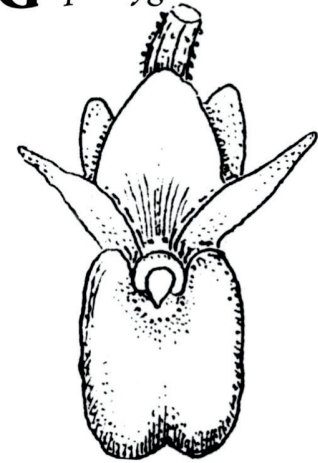

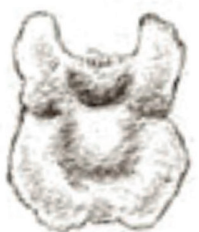

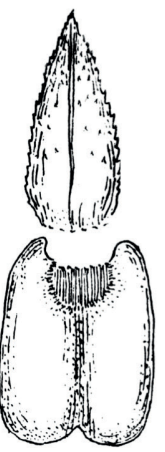

E asperula
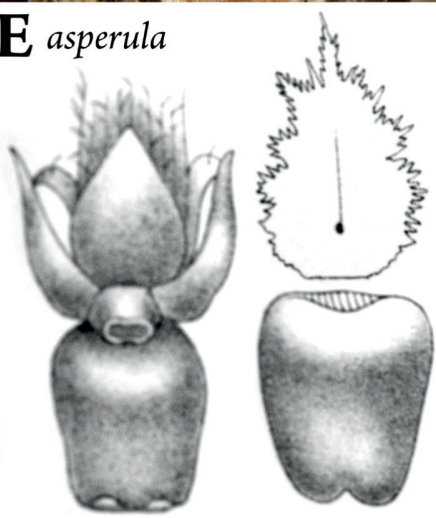

$\mathbf{H}$

crassilabris

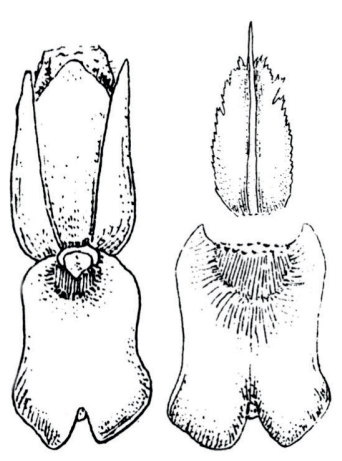

Figure 2. Oberonia heliophila and its synonyms. A. Flowers from lectotype of $O$. heliophila W37726. B. Flowers on MICH

syntype of $O$. hosokawae. C-H. Drawings of flower, isolated lip, and bract. C. Original figures of O. rivularis from Schlechter (1911). D. Drawing of flower of O. inversiflora by J.J. Smith (from Schuiteman \& deVogel 2006). E. Illustration of flower of $O$. asperula from Smith (1909). F. Illustration of $O$. dolichophylla from Schlechter (1923); the bract was not figured. G. Illustration of $O$. pachyglossa from Schlechter (1923). H. Illustration of $O$. crassilabris from Schlechter (1923). Scale bars A, B = $1 \mathrm{~mm}$.

included $O$. heliophila from Fiji and $O$. betchei from Samoa in his section Scytoxiphium, those species were not mentioned again. Schlechter (1911: 177, translated from German) noted under $O$. pachyglossa that “... in Scytoxiphium the individual species are always closely related amongst each other and not only in the same 
areas, but also in widely separated regions, whose floras tend to have little in common." Despite morphological similarities, he discounted those similarities a priori because species distributed over larger areas was considered highly improbable. In Schlechter's opinion, there was no need of comparing the New Guinea species to those from areas further away.

Smith $(1908,1912)$ described $O$. asperula and $O$. inversiflora J.J.Sm., the latter explicitly in the section Scytoxiphium, introduced one year earlier. It demonstrates that Smith was aware of Schlechter's (1911) work on the orchids of New Guinea. However, neither of Smith's species were compared to any other. Smith is known to have been an extreme splitter, even in cases where he wondered whether his species had already been described, such as $O$. salakana J.J.Sm. [ $=$ O. merapiensis Schltr. as discussed in Geiger (2019)]. The lack of comparisons, the $\mathrm{n}=1$ problem, and Smith's demonstrated tendency to excess splitting make his taxa highly suspicious.

Oberonia hosokawae Fukuy. (in Hosokawa 1941) was also described in section Scytoxiphium. While the membership in the section appears to have been discussed in the remarks in Japanese, no other species assigned to the section seems to have been discussed. The lack of comparison and the $\mathrm{n}=1$ problem make this species equally suspicious. The specific epithet was erroneously corrected to hosokawai by Geiger (2020a), an error noted by Geiger (2020b).

The synonymy of several of the species under $O$. heliophila has been discussed elsewhere (Geiger 2020a): O. asperula, O. rivularis, O. inversiflora, $O$. hosokawae. Oberonia pachyglossa Schltr. has been treated as a synonym of $O$. heliophila by WCSP (2020); I have not been able to trace a literature reference for the establishment of this synonymy. Oberonia crassilabris and $O$. dolichophylla are still recognized species. These three species are formally synonymized here.

\section{TAXONOMIC TREATMENT}

The type concepts used are in strict accordance with the ICN (McNeill 2014, 2015). Isotypes are duplicate specimens of the same gathering as the holotype explicitly specified with a repository in the protologue. If no holotype was specified, then all specimens are referred to as syntypes, even if from a single gathering.
Oberonia heliophila Rchb.f. (1878: 56). (Fig. 2-7).

TYPE: U.S. Exploring Expedition s.n. (lectotype W37726: designated by Kores 1989), Mountains of Mathuata Province, Vanua Levu, Fiji. The rather convoluted assessment of other type material has been discussed elsewhere (Kores 1989, Geiger 2020a). Thanks to Paul Omerod (pers. comm.) the Gräffe s.n. [1257] syntypes from Upolu, Samoa, were recently found at HBG 501809 and HBG 500445; an additional duplicate is at MO 4338405. While the collector was spelled "Graeffe" in Reichenbach's (1878: 56) Latin protologue, the label spells the name with an umlaut.

Syn.: Oberonia dolichophylla Schltr. in Schumann and Lauterbach (1905: 114). Schlechter 1923: pl. 69, fig. 248.

TYPE. Schlechter 14579 (syntype: B, lost). At the river board of the Garup, at the foot of the Toricelli mountains [Papua New Guinea], $100 \mathrm{~m}$, syn. nov.

Syn.: Oberonia pachyglossa Schltr. 1911: 177. Schlechter 1923: pl. 69, fig. 249.

TYPE. Schlechter 16756 (syntype: B, lost). Forests at the Kaulo [River, Madang, Papua New Guinea] $400 \mathrm{~m}$, syn. nov.

Syn.: Oberonia crassilabris Schltr. 1911: 177; Schlechter 1923: pl. 69, fig. 250.

TYPE. Schlechter 17948 (syntype: B, lost). Forest of the Finisterre mountains, Papua New Guinea, 700 $\mathrm{m}$, syn. nov.

Material examined: Country unknown. Wight 441 (MEL s.n.), Arbor dolan. Fiji. Degener 15465 (F 1473815, K s.n., MO 1256922, MICH s.n., P 00310689), Ra, vicinity of Rewasa, near Vaileka. Degener \& Ordonez 14166 (K s.n.), Thakaundrove, Marvu, near salt lake. Gillespie 3877 (K s.n.), Valley of Kalindina near Nambai, Namosi Province. Greenwood 603 (K s.n.), Mount Mamata coast. Greenwood 709 (K s.n.), Haulikno, N side. Greenwood 1113 (K s.n.), Naitasiri, near Nasinu. Praham 30 (BM 000088476), Vanua Levu. Smith 7075 (K s.n., P 00310688), Tailevu, Hills E of Wainimbuka River vicinity of Ndakuivuna. Parks 20174 (K s.n). Indonesia. Comber 1373 (K s.n.), Rannpane, N of Semeru. New Guinea. Carr 10045 (BM s.n., CANB 46410, CANB 46321, SING 0141494, SING 0141462 K s.n.), Koitaki. Carr 10667 (B s.n., BM 000088448, CANB 46443, F 1497506, K s.n., P 00364412, SING 0141482, SING 0141483), Kokoda. Conn 544 (MEL 1528545), Gulf Province, N side of Lake Tebera. Reeve 923 (CANB 8500636), Lagaip District. O'Byrne O.020 (SING 


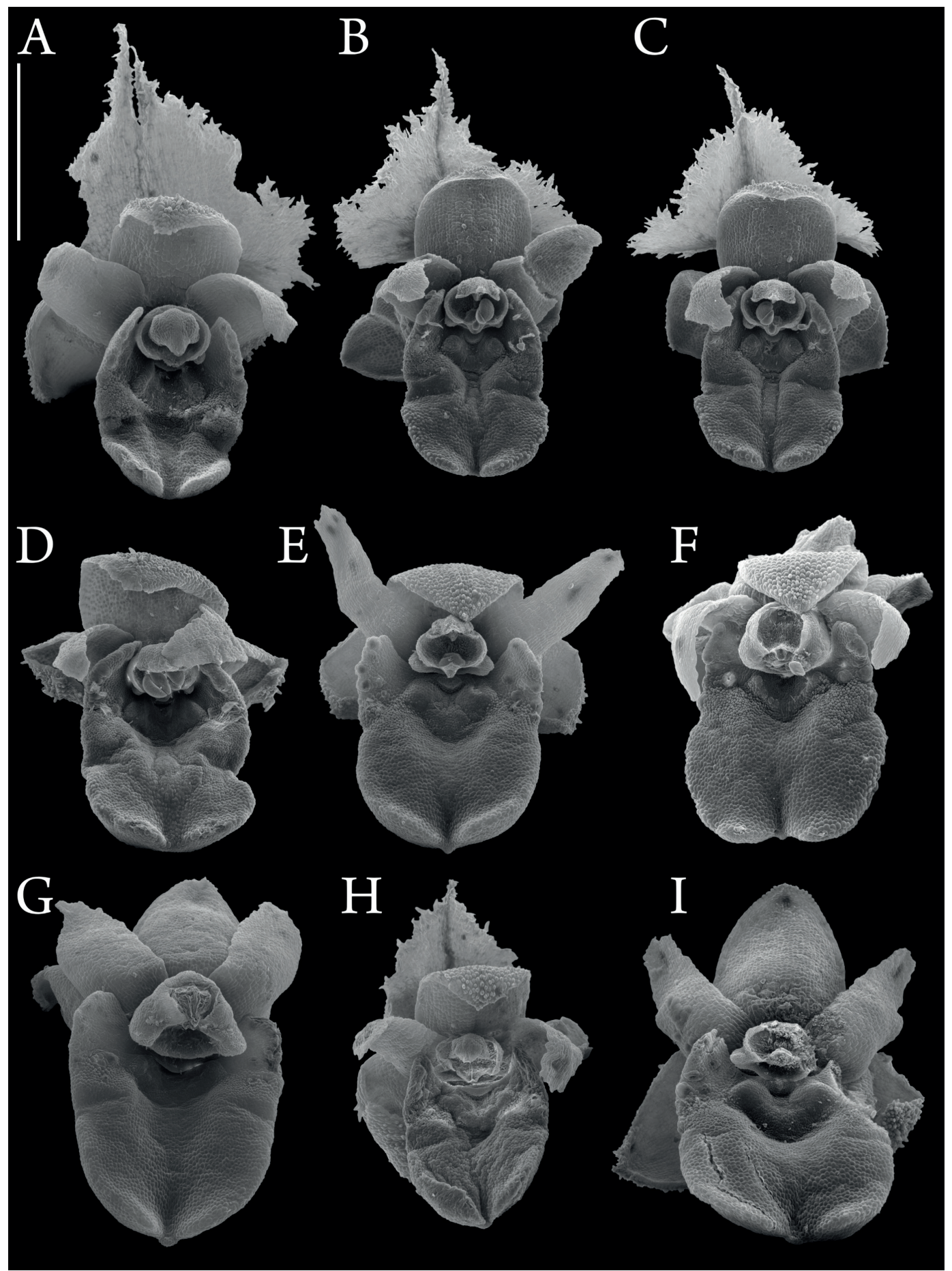

Figure 3. Oberonia heliophila SEM images of face of flowers. A. Schuiteman 90/555 L 23197 from Papua New Guinea. B-C. Harris 1514 L 19688 from Papua New Guinea. D. deVogel s.n. L 20059 from New Guinea. E. Mulder s.n. L22448 from Fiji. F. Hunt 2226 K28510 from the Solomon Islands. G. M.A. Clements 5603 CANB 8916245, from Vanuatu, live image in Figure 6H. H. Mason 1645 K 7169, from Fiji. I. Mulder s.n. L 24117 Fiji. Scale bar $=1$ mm. 


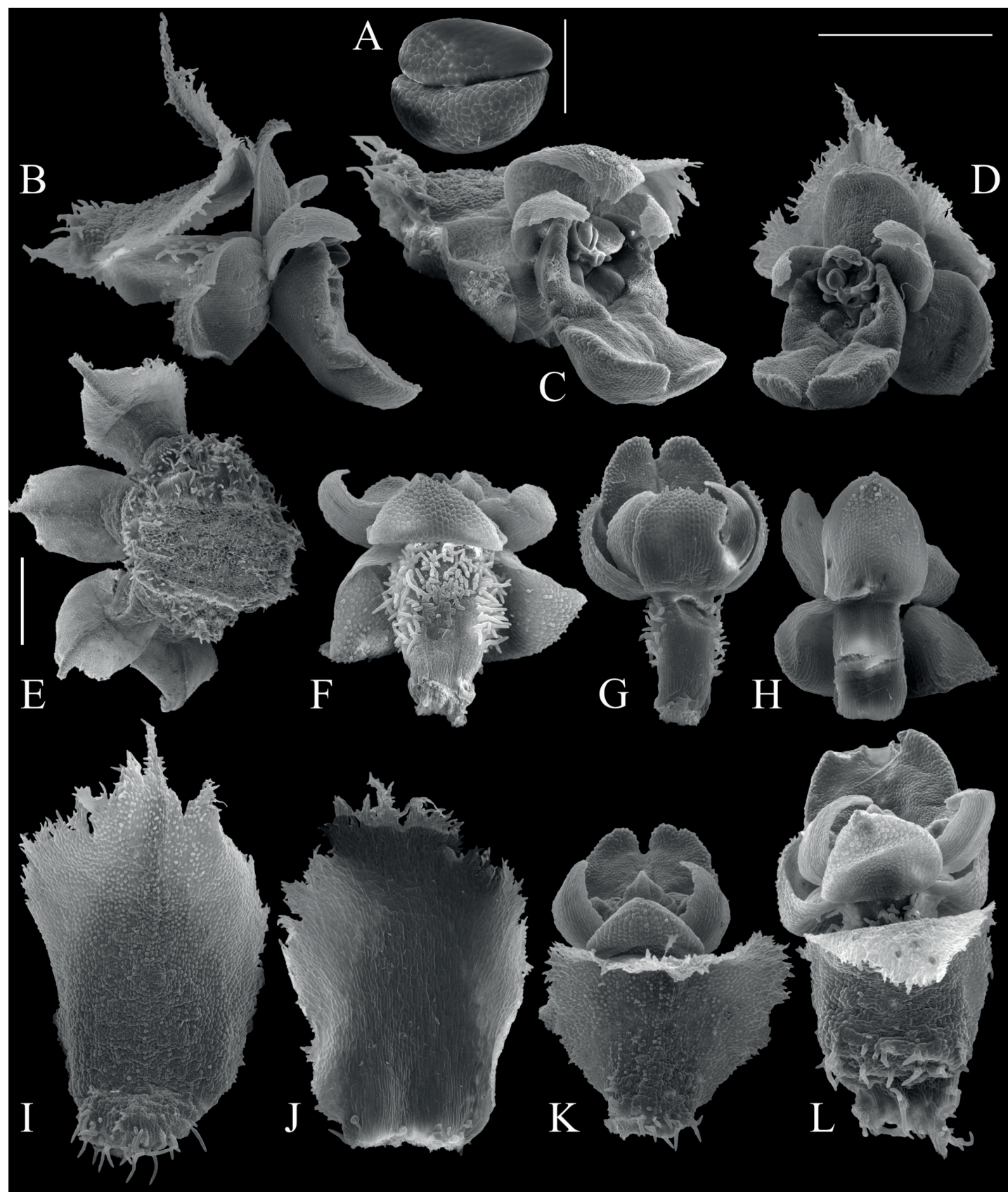

Figure 4. Oberonia heliophila SEM images. A. Pollinaria. Scale bar $=100 \mu \mathrm{m}$. B. Flower lateral with curved up bract and sparse hairs on pedicelled ovary. C-D. Oblique view of flower showing thick lip. E. Cross section though rachis with several attached bracts. Scale bar $=1 \mathrm{~mm}$. F-H. Top of view of flower without bracts showing variable degree of hairs on pedicelled ovary. I-J. isolated floral bract. I. External view. J. Internal view. K. Top view of flower with spreading bract. L. Top view of flower with clasping bract. Scale bar except A, E = $1 \mathrm{~mm}$. A, I, J. deVogel s.n. L20059 from New Guinea. B, D, G, K. Harris 1514 L19688 from Papua New Guinea. C. deVogel s.n. L20059 from New Guinea. E, F. Hunt 2226 K28510 from the Solomon Islands. H. Schuiteman 90/555 L23197 from Papua New Guinea. L. Leg. ign.. s.n. K 21001, loc. ign. 


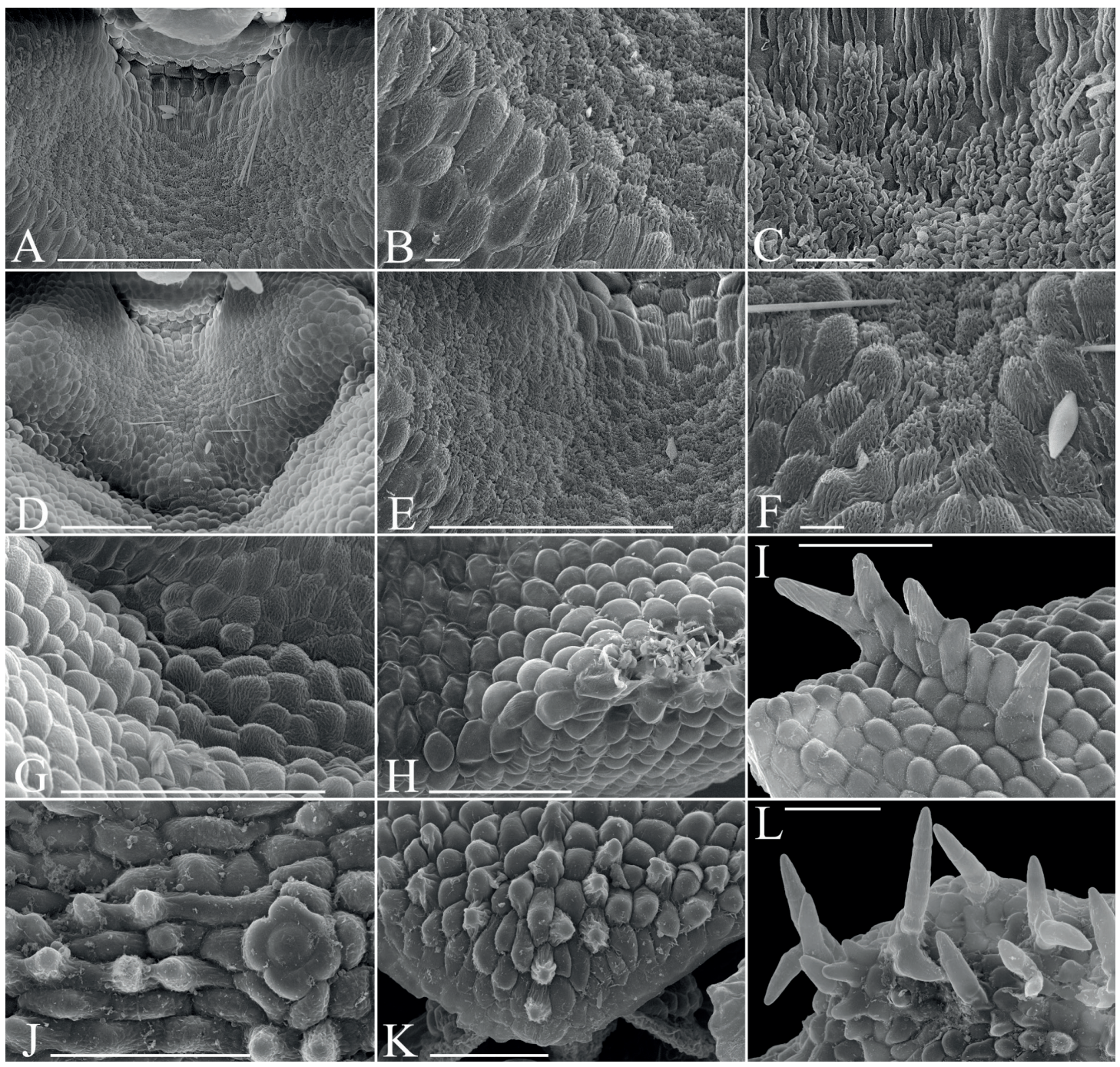

FIgurE 5. Floral details of Oberonia heliophila. A, D. Disc area with sac. Scale bar $=100 \mu \mathrm{m}$. B. Transition between mesochile with elongaged moderately rugulate cells to disc with round strongly rugulate cells. Scale bar $=10 \mu \mathrm{m}$. C. Transition between disc with round strongly rugulate cells to sac with rectangular striate cells. Scale bar $=10 \mu \mathrm{m}$. E. Transition from mesochile (lower left) through disc (center) to sac (upper right). Scale bar $=100 \mu \mathrm{m}$. F. Median tip of disc (round strongly rugulate cells) and mesochile (elongated moderately rugulate cells). Scale bar $=10 \mu \mathrm{m}$. G. Transition between mesochile and epichile with crease and and reduction in rugulosity. Scale bar $=100 \mu \mathrm{m}$. H. Edge of thick epichile. Ruptured cells with mineral deposits. Scale bar $=100 \mu \mathrm{m}$. I, L. Trichome ridge on lateral sepals. Scale bar $=$ $100 \mu \mathrm{m}$. J. Top surface of bract with short trichomes and cross cells. Scale bar $=100 \mu \mathrm{m} . \mathbf{K}$. Tip of median sepal with rugulate-mammilate cells. Scale bar $=100 \mu \mathrm{m}$. L. Trichomes at base of bract. Scale bar $=100 \mu \mathrm{m}$. (A-I: deVogel s.n. L 20059 from New Guinea. J-L: Harris 1514 L 19688 from Papua New Guinea).

0141441), Papua New Guinea. Reeve 5397 (K s.n.), Seargu [Beneni] SW side of Lak Kutubu, Nipa District, Southern Highlands. Samoa. Mansfeld 146 (P 00310612), near Malololelei. Mansfeld 1882 (K s.n.), Matavanu. Vaupel 234 (K s.n., MO 1614357), Matautu. Walter s.n. (MEL 2394315), Samoa. Whistler W2790 (K s.n.), W of Aoloaufou. WhitLANKESTERIANA 21 (2). 2021. (C) Universidad de Costa Rica, 2021. mee 43 (MEL 2394729), Samoa. Whitmee 45 (K s.n.), Samoa. Whitmee 48 MEL 2394730), Samoa. Whitmee 165 (K s.n.), Samoa. Whistler W1702 (K s.n.), N of Potlacthc Lumber Mill at Asau. Solomon Islands. Hunt 2226 (K s.n.), 1/4 mile below confluence of Warahito and Pegato rivers. Wickison 87 (K s.n.), Chariveghu Drainage system. 

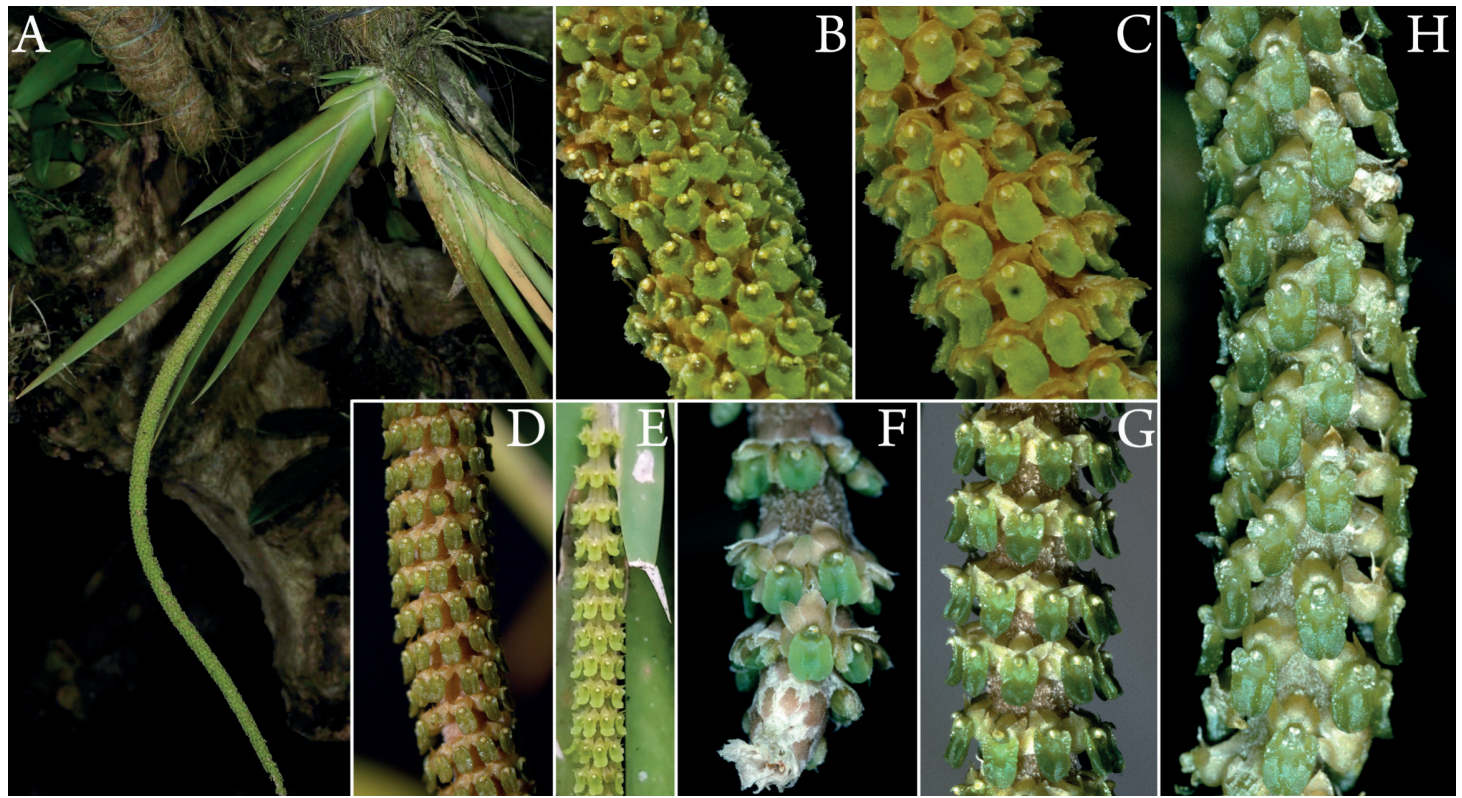

Figure 6. Live Oberonia heliophila. A-C. Cultivated plant from Papua New Guinea, collection and photographs Jeffrey Champion. A. Habit. B. Flowers of plant shown in A, first flowering with flowers scattered on inflorescence. C. Flowers of plant shown in A, second flowering, with flowers in whorls. D. Flowers of plant in cultivation from Papua New Guinea at Leiden Botanical Garden 20031565, photograph by Eduard de Vogel. E. Almost entirely green flower in plant in cultivation from Papua New Guinea, collection and photograph of Maryse Devaeve. F. Flowers of Clements KK6916 from Simbai, New Guinea. G. Flowers of Clements 5392 from Efate, Vanuatu. H. Flowers of Clements 5603 from Santo, Vanuatu; SEM image in Figure 3G. F-H. Photographs by Mark Clements.

Vanuatu. Clements 5603 (CANB 8916245), $30 \mathrm{~km} \mathrm{~W}$ of Luganville, Santo, Wounauss Village area. Morrison s.n. (K s.n.), Gulley near Amlganhat, Aneityum mountain. Wallis and Futuna. Pillon 895 (P 02102968 ), Wallis, Mout Lulu Fakahega. MacKee 39257 (P 00310691 , P 00310690), Wallis, Mount Lulu.

Notes: Oberonia dolichophylla is a synonym of $O$. heliophila. There are no known surviving syntypes of Schlechter 14579. Schlechter 19997 of O. dolichophylla at BO (Cribb \& Robbins 1990: a duplicate of the now destroyed B specimen) is not a syntype but a voucher for the species' listing in Schlechter (1911). The species was described as rather large for an acaulescent Oberonia $(45 \mathrm{~cm})$, with pointed and hairy bracts, green flowers, oblique lanceolate petals, lip oblong with truncated end [= subquadrate], and the epichile with a shallow notch. All these characters agree with $O$. heliophila. Schlechter in Schumann \& Lauterbach (1905) compared his O. dolichophylla only known from the type Schlechter 14579 with $O$. rivularis only known from the type Schlechter 13801. It is an example of comparing specimens instead of species and the $n=1$ problem discussed above. He noted the longer inflorescence, bracts and lip, as well as thicker leaves in O. dolichophylla. The length of the inflorescence is meaningless in Oberonia as has been shown from plants grown in cultivation (cf. Geiger 2018, 2019). The diameter of the inflorescence is given as 1 $\mathrm{mm}$ in $O$. rivularis and $2 \mathrm{~mm}$ in $O$. dolichophylla, the bracts are approximately $1.5 \mathrm{~mm}$ long in $O$. dolichophylla and $1 \mathrm{~mm}$ in $O$. rivularis, and the lip is given as $2 \mathrm{~mm}$ long in $O$. dolichophylla and slightly $>1 \mathrm{~mm}$ in $O$. rivularis. Whether those measurement are accurate is unknown and unverifiable as the material at B was destroyed. Inaccuracies in measurements and scale bars have been documented previously (Geiger 2019). Given that the comparisons are based on single specimens $(\mathrm{n}=1$ each), those small differences are not sufficient to justify species-level differentiation.

Oberonia pachyglossa is a further synonym of $O$. heliophila. The name has rarely been mentioned in the literature since its initial publication. O'Byrne's (1992, 1994) voucher (SING 0141441) can be referred to $O$. heliophila, while Schuiteman and de Vogel (2006) 

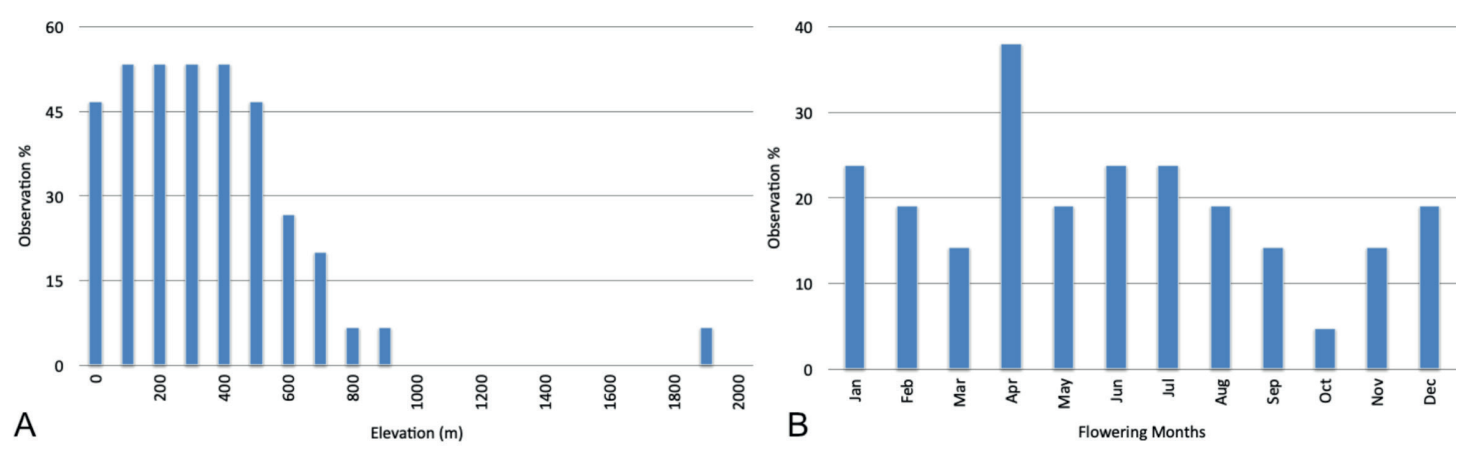

Figure 7. Ecological data for Oberonia heliophila. A. Elevation, $\mathrm{n}=16$. B. Phenology, $\mathrm{n}=22$. (references under any known synonym. Elevation: Christophersen 1935, Cribb \& Whistler 1996, Fukuyama in Hosokawa 1941, Hawkes 1952, Kores 1991, Lewis \& Cribb 1991, Millar 1999, O’Byrne 1994, Schlechter 1911, Schlechter in Schumann \& Lauterbach 1905, Schuiteman \& de Vogel 2006, herbarium records. Phenology: Christophersen 1935, O‘Byrne 1994, Reichenbach 1878 , Schlechter 1910, 1911, Schlechter in Schumann \& Lauterbach 1905, Schuiteman \& de Vogel 2006, Smith 1909, 1915 , herbarium records).

reproduced Schlechter's (1923) figure. The species was described as being of large habit $(55 \mathrm{~cm})$, having dentate bracts, green flowers, linear-lingulate petals, with a thick, subquadrate lip with small auricles and somewhat truncated epichile. All these characters agree with $O$. heliophila. Schlechter considered $O$. pachyglossa only known from type Schlechter 16756 and $O$.dolichophylla only known from type Schlechter 14579 as distinct based on the slenderer inflorescence (3 mm in O.dolichophylla, no measurements given for $O$. pachyglossa) and the linear petals. The claim about the width of the inflorescence cannot be evaluated due to lack of data. The shape of the petals is continuously variable in $O$. heliophila (Fig. 3); bimodal distribution, pattern, or covariance cannot be identified. The simpler explanation is variability in this character, rather than postulating multiple, almost cryptic species with additional intermediates that cannot be clearly assigned to any of the postulated species.

Oberonia crassilabris is a synonym of $O$. heliophila. The taxon has been designated as the type species of the section Scytoxiphium by van Royen (1979) and a second time by Schuiteman and de Vogel (2006), who copied Schlechter's figure. The type specimen was described as large $(60 \mathrm{~cm})$, with deeply incised bracts, tepals with a green lip with remaining tepals brownish, thick lip, subquadrate with small auricles and bilobed epichile over one quarter of lip length. All these characters agree with $O$. heliophila. Schlechter considered $O$. crassilabris only known from type Schlechter 17948 and $O$. dolichophylla only known from type Schlechter 14579 as distinct based on the oblique lanceolate vs. oval lanceolate petals, and the depth of the incision of the epichile of the lip. As indicated above, the shape of the petals is variable, and the alleged differences are at best slight. The depth of incision of the epichile is equally variable with no pattern discernible (Fig. 3).

A syntype of $O$. betchei Schltr. was found in MEL and confirms the synonymy with $O$. heliophila (Geiger pers. obs.).

Plant large, acaulescent, fan-shaped, leaves to $75 \times$ $1.6 \mathrm{~cm}$, acuminate, laterally compressed, fleshy; flowering plants as small as $25 \mathrm{~cm}$. Inflorescence terminal, to $64 \mathrm{~cm}$ long, flowers typically in clearly separated whorls (Fig. 6C-F), occasionally scattered (Fig. 6B, $\mathrm{H})$. Bract as long as flower to somewhat longer, typically curved upwards (Fig. 4A, D, K, L), typically wider than flower, occasionally as wide as flower, triangular acuminate, at base hirsute, at tip strongly dentate, occasionally laciniate (Fig. 3B-C, 4D, I-L), frequently with 1-2 terminal awns (Fig. 3A). Pedicelled ovary rather short for genus, strongly pubescent towards flower to glabrous (Fig. 4B, F-H). Flower with lip in green tones, remainder of tepals typically in shades of tan (Fig. 4E-H), occasionally yellowish (Fig. 4B-C), occasionally entire flower light green (Fig. 4E). Considerable variation in flower color on same inflorescence (O’Byrne 1994: as O. pachyglossa). Sepals triangular, sometimes with sparse short hairs abaxially (Fig. 4C, 
F). Petals narrowly ovoid to lanceolate, about as long as sepals. Lip thickened (Fig. 4B-C), auricles extending to middle of gynostemium; indistinct lateral lobes with irregular margins (Fig. 3, 4C-D); disc with shallow sac (specific shape affected by preservation: Figs 3, 4C-D, 5A, D) flanked by thickened pads of variable shape and distinction; indistinct constriction in middle of lip (Figs. 3, 4C-D, 5D); epichile broad with more or less distinct apical notch separating two lobes (Fig. 3). Gynostemium short and thick for genus. Pollinaria composed of two pollinia of unequal size, kidney shaped, without caudicle or viscida (Fig. 4A).

Cell surface morphologies consisting of striate around disc (Fig. 5C, E), coarsely rugulate around mesochile end, central portion of epichile (Fig. 5C, F), finely rugulate on main portion of mesochile and epichile (Fig. 5A, B, G), glabrous pneumate at tips of epichile (Fig. 5H). Short rugulate trichomes on the backside of the sepals (Fig. 5J, K), longer uniserial trichomes at base of bract (Fig. 5L).

The arrangement of flowers in whorls and scattered is variable as demonstrated by repeat flowering of same plant in cultivation, based on photographs taken by J. Champion (Fig. 6A-C). The presence and density of the hairs on the pedicelled ovary varies continuously with no patterns discernible. A few conditions are illustrated here: dense hairs (Fig. 4F), scattered hairs (Fig. 6B), sections variously hairy and glabrous (Fig. $4 \mathrm{G})$, glabrous (Fig. 4H).

Distribution: Indonesia (Java: Comber 1373 K s.n.), Fiji, Micronesia, New Guinea, Samoa, Solomon Islands, Vanuatu, Wallis and Futuna (citation under any of the known synonyms: Cribb \& Whistler 1996, Hawkes 1952, Kores 1989, 1991, Lewis \& Cribb 1989, 1991, Millar 1999, O’Byrne 1994, Parham 1972, Reichenbach 1878, Schlechter 1910, 1911, Schuiteman \& de Vogel 2006, Smith 1908, 1912, 1915, Williams 1938, 55 herbarium records: B, BM, CANB, F, K, MEL, MICH, MO, NSW, P, SING, US, W).

ECOLOGY: Mostly pendulent, occasionally erect, branch and trunk epiphyte on mangrove trees, bread fruit ( $\mathrm{Ar}$ tocarpus altilis: Moraceae), Hevea (Euphorbiaceae), Terminalia catappa (Combretaceae), Pterocarpus (Fabaceae), Pometia (Sapindaceae), mahogany (Swietenia humilis: Meliaceae), Melaleuca sp. (Myrtaceae) and palms (Cocos nucifera, Metroxylon sp.). In coastal to montane forest, sun exposed. The species flowers throughout the year (Fig. 7B).

Oberonia heliophila is found regularly from sea level to about $500 \mathrm{~m}$, with decreasing frequency to 900 $\mathrm{m}$ (Fig. 7A). The single record from $1900 \mathrm{~m}$ (Comber $1373 \mathrm{~K}$ s.n. from Java) needs verification. The elevation at the named location matches the indicated elevation based on GoogleEarth. That record could be mislocalized. However, a photograph by Mark Clements of the species was taken around Simbai, New Guinea, which is at approximately 1900 m elevation, including its surroundings (Fig. 4E).

Cultivation: This warm growing species can be cultivated on tree fern slabs, possibly with some coco fiber pad, ideally in bright shade (lath house), but tolerating wide range of light, with high humidity, daily watering, and excellent ventilation (O’Byrne 1994, Schuiteman \& de Vogel 2006, J. Champion pers. comm.).

Discussion. One reviewer criticized that the findings here are not supported by molecular data, therefore, are only an unsubstantiated opinion. A similar position was advanced by Jones (2021) with respect to the Australian Oberonia names synonymized by Geiger (2019). Such a point of view is ill founded for the following reasons.

1) Taxonomic assessments are based on types. Type specimens cannot be destructively sampled. Taxa with lost types have no chance of being evaluated based on genetic data, which applies to all three names synonymized here. Taxonomic assessment is based by necessity on the available information, such as herbarium sheets, illustrations and the protologue.

2) If species can be described based on morphology, then they can also be synonymized based on morphology. An asymmetry of evidentiary burden is unjustifiable. Otherwise, one would have to require all new species descriptions to be supported by molecular data as well. The vast majority of species descriptions even today are based exclusively on morphology, some notable exceptions notwithstanding.

3) The inclusion of molecular data does not guarantee a better outcome. Questions such as selection of marker(s), choice of analytical settings, choice of ingroup and outgroup taxa, mistakes in the laboratory (contamination), and identification of material all har- 
bor potential for erroneous results. There is no question that molecular data have produced tremendous advances in systematic biology, and I have used those techniques myself. However, there have also been high-profile blunders.

4) The insistence on using molecular data would invalidate all systematic paleontology.

Additionally, the main point made here of incorporating intraspecific variability into taxonomic assessments is supported by molecular data from better known species, such the molecular phylogeny of O. equitans (Forster) Mutel by Geiger et al. (2020a) including fine morphological examination of flowers. Extensive morphological variability is also suggested by the molecular phylogeny of Li et al. (2016), which showed six samples of $O$. austro-yunnannensis S.C.Chen \& Z.H.Tsi and ten samples of $O$. jenkinsiana Griff. ex Lindl. in a completely unresolved polytomy with extremely short terminal branches. This is a strong indication of synonymy.

Last but not least, scientific progress is incremental, and all taxonomic assessments are opinions, whether supported by morphology or molecular data. Additional information can either lead to confirmation of an earlier result, or it can lead to a new hypothesis being advanced. I welcome a re-examination of this proposal.

Conclusion. Within Oberonia sect. Scytoxiphium, taxonomic ranks have typically been employed at one level higher than is appropriate for species recognition. Specimens were named as species, while the single species was treated as a section. The underlying reason is typological thinking, not considering intraspecific variability, assuming limited distribution of species, and failing to review literature. The section is reduced from eight species to one. Distribution of the section ranges from Java through Micronesia to Samoa.

ACKNowledgements. Many thanks to Jeffrey Champion, Mark Clements, Maryse Devaeve, and Eduard de Vogel for permitting me to use their photographs. André Schuiteman (K), Brendan Lepschi (CANB), Barbara Gravendeel and Christel Schollaardt (L), and Sean Lahmeyer (HNT) facilitated loans of material. Robert Vogt and Nils Köster (B), Jacek Wajer (BM), Brendan Lepschi and Mark Clements (CANB), Christine Niezgoda (F), André Schuiteman (K), Wayne Gerbet (MEL), Brad Ruhfel (MICH), James Solomon and Donna Herrera (MO), Katharine McCroll and Peter Weston (NSW), Marc Pignal (P), Balizah Mohd Ibrahim, Hubert Kurzweil, Paul Leong, Serena Lee (SING), Rusty Russell (US), and Ernst Vitek (W) provided accommodations during collection visits. Matthias Schulz and Marko Saggau (HBG) kindly provided photographs and high-resolution scans of the HBG Gräffe types. The reviewers helped with constructive comments to improve the manuscript.

\section{LiTERATURE CITED}

Ansari, R. \& Balakrishnan, N. P. (1990). A revision of the Indian species of Oberonia (Orchidaceae). Orchid Monographs, 4, i-iv, 1-82, pls. 1-3.

Averyanov, L. V., Nguyen, K. S. \& Maisak, T. (2019). Plant diversity, flora and vegetation of Hin Nam No protected area. Bea Bassin, Mauritius: Lambert Academic Publishing.

Barthlott, W., Grosse-Veldmann, B. \& Korotkova, N. (2014). Orchid seed diversity, a scanning electron microscopy survey. Englera, 32, 1-245.

Bunpha, K.-O., Sridith, K. \& Pedersen, H. Æ. (2019). A taxonomic revision of Oberonia (Orchidaceae: Epidendroideae: Malaxideae) in Thailand. Phytotaxa, 420, 102-156.

Chen, S. C. (2003). Hippeophyllum microphyllum, a new species of Orchidaceae from Papua New Guinea. Novon, 13, $180-181$.

Chowlu, K., Devi, Y. N., Rao, A. N., Angela, N., Sharma, H. B. \& Akimpou, G. (2015). Oberonia manipurensis sp. nov. (Orchidaceae) from Manipur, India. Nordic Journal of Botany, 33, 42-44.

Cribb, P. J. \& Whistler, W. A. (1996). Orchids of Samoa. Kew: Royal Botanical Gardens.

Cribb, P. J. \& Robbins, S. (1990). The New Guinea orchid collection of Rudolf Schlechter in Herbarium Bogoriense. Lindleyana, 5, 244-248.

Christophersen, E. (1935). Flowering plants of Samoa. Bernice P. Bishop Museum Bulletin, 128, 1-221 [1971 reprint examined]. 
Geiger, D. L. (2003). Phylogenetic assessment of characters proposed for the generic classification of Recent Scissurellidae (Gastropoda: Vetigastropoda) with a description of one new genus and six new species from Easter Island and Australia. Molluscan Research, 23, 21-81.

Geiger, D. L. (2012). Monograph of the little slit shells. Santa Barbara: Santa Barbara Museum of Natural History.

Geiger, D. L. (2014). Oberonia, the microscopist's delight. ORCHIDS, 83, 558-563.

Geiger, D. L. (2016). Severnsia strombeulima n. gen. \& sp. from Hawaii (Mollusca, Gastropoda: Caenogastropoda: Eulimidae). Zootaxa, 4084, 587-589.

Geiger, D. L. (2018). Studies in Oberonia [4]: An herbarium of cultivated orchids: why and how. Orchid Digest, 82,92-98.

Geiger, D. L. (2019). Studies on Oberonia 5 (Orchidaceae: Malaxideae). Twenty-four new synonyms, and a corrected spelling. Blumea, 64, 123-139.

Geiger, D. L. (2020a). Studies in Oberonia 8 (Orchidaceae: Malaxideae). Additional 24 new synonyms, a corrected spelling, and other nomenclatural matters. Blumea, 65, 188-203.

Geiger, D. L. (2020b). Correction. Geiger (2020: Blumea 65: 188-203). Studies in Oberonia 8. Blumea, 65, 204.

Geiger, D. L., Crain, B. J., McCormick, M. K. \& Whigham, D. F. (2020). Studies on Oberonia 7. Ten new synonyms of Oberonia equitans (G.Forst.) Mutel indicated by morphology and molecular phylogeny. ORCHIDS/Lindleyana, 89, 656-667.

Geiger, D. L., Sulaiman, M. \& Murugan, C. (in press). Studies in Oberonia 10. A re-evaluation of Oberonia brachystachys Lindl. and O. subligaculifera J.J.Sm. (Orchidaceae: Malaxideae) and their synonyms. Rheedea.

George, K. V., Mathew, J. \& Antony, S. (2019). Oberonia saint-berchmansii (Orchidaceae): A new species from south Western Ghats, India. Species, 20, 110-113.

Gilli, A. (1983). Beiträge zur Flora von Papua-New Guinea. III Molocotyledones. Annalen des Naturhistorischen Museums Wien, B84, 5-47.

Goldstein, J. I., Newbury, D. E., Echlin, P., Joy, D. C., Roming, Jr., A. D., Lyman, C. E., Fiori, C. \& Lifshin, E. (1992). Scanning electron microscopy and x-ray microanalysis. A text for biologists, material scientists, and geologists. New York: Plenum Press.

Hawkes, A. D. (1952). Notes on a collection of orchids from Ponape, Caroline Islands. Pacific Science, 6, 3-12.

Hosokawa, T. (1941). Material of the botanical research towards the flora of Micronesia XXI. Transactions of the Natural History Society of Formosa, 31, 289-291.

Jones, D. L. (2021). A complete guide to native orchids of Australia. Sydney: Reed New Holland.

Josephson, J. R. \& Josephson, S. G. (1993). Abductive inference. Cambridge: Cambridge University Press.

Karremans, A. P., Chinchilla, I. F., Rojas-Alvarado, G., Cedeño-Fonseca, M., Damián, A. \& Léotard, G. (2020). A reappraisal of neotropical Vanilla. With a note on taxonomic inflation and the importance of alpha taxonomy in biological studies. Lankesteriana, 20, 395-497.

Kores, P. J. (1989). A precursory study of Fijian orchids. Allertonia, 5, 1-222.

Kores, P. J. (1991). Orchidales. In: A. C. Smith (Ed.), Flora vitiensis nova, a new flora of Fiji (spermatophytes only) Volume 5 (pp. 321-576). Lawai: National Tropical Botanical Garden.

Lewis, B. \& Cribb, P. J. (1989). Orchids of Vanuatu. Kew: Kew Botanical Gardens.

Lewis, B. \& Cribb, P. J. (1991). Orchids of the Solomon Islands and Bougainville. Kew: Kew Botanical Gardens.

Li, Y., Tong, Y. \& Xing, F. (2016). DNA barcoding evaluation and its taxonomic implication in the recently evolved genus Oberonia Lindl. (Orchidaceae) in China. Frontiers in Plant Science, 7, Article 1791, 1-9.

Mahner, M. \& Bunge, M. (1997). Foundations of biophilosophy. Berlin: Springer.

Mayr, E. (1994). Typological versus population thinking. In: E. Sober (Ed.), Conceptual issues in evolutionary biology (pp. 157-160). Cambridge, Mass: MIT Press.

McNeill, J. (2014). Holotype specimens and type citations: general issues. Taxon, 63, 1112-1113.

McNeill, J. (2015). Corrigendum to 'Holotype specimens and type citations: general issues' [Taxon 63: 1112 -1113. 2014]. Taxon, 64, 183.

Millar, A. (1999). Orchids of Papua New Guinea. Portland: Timber Press.

Moore, M., Jameson, M. E. \& Paucar-Cabrera, A. (2014). Taxonomic vandalism is an emerging problem for biodiversity science: A case study in the Rutelini (Coleoptera: Scarabaeidae: Rutelinae). Entomological Society of America 62nd Annual Meeting, Portland, Oregon, November 16-19, 2014.

O’Byrne, P. (1992). A survey of the lowland orchids of Papua New Guinea. Privately published report. [NSW library Q584/050 95 P.N.G. O] 
O’Byrne, P. (1994). Lowland orchids of Papua New Guinea. Singapore: National Parks Singapore.

Páll-Gergeley, B., Hunyadi, A. \& Auffenberg, K. (2020). Taxonomic vandalism in malacology: Comments on molluscan taxa recently described by N. N. Thach and colleagues (2014-2019). Folia Malacologica, 28, 35-76.

Parham, J. W. (1972). Plant of the Fiji Islands, revised edition. Suva: Government Printer.

Popper, K. R. (1983). Realism and the aim of science. London: Routledge.

Ray, S. (2002). Applied photographic optics. Third Edition. Oxford: Focal Press.

Reichenbach, H. G.f. (1878). Orchideae Wilensianae indescriptae. Otia Botanica Hamburgensia, 1, 50-56.

Schlechter, R. (1910). Revision der Orchidaceen von Deutsch-Samoa. Fedde Repertorium Speciarum Novarum Regni Vegetabilis, 9, 82-96.

Schlechter, R. (1911). Die Orchideen von Deutsch-Neu-Guinea. Fedde Repertorium Speciarum Novarum, Regni Vegetalis, Beihefte, 1, LXVI, 1-1079.

Schlechter, R. (1923). Figuren-Atlas zu den Orchideen von Deutsch-Neu-Guinea. Fedde Repertorium Speciarum Novarum, Regni Vegetalis, Beihefte, 21, pls. 1-372.

Schlechter, R. (1934). Blütenanalysen neuer Orchideen IV. Indische und malesische Orchideen. Fedde Repertorium Speciarum Novarum, Regni Vegetalis, Beihefte, 74, 1-9, pls 1-85.

Schuiteman, A. \& de Vogel, E. F. (2006). Flora malesiana: orchids of New Guinea vol. IV. Genera Kuhlhasseltia to Ophioglossella. CD ROM. Amsterdam: ETI.

Schumann, K. \& Lauterbach, K. (1905). Nachträge zur Flora der deutschen Schutzgebiete in der Südsee (mit Ausschluss Samoa's und der Karolinen). Leipzig: Gebrüder Borntraeger.

Seidenfaden, G. (1978). Orchid genera of Thailand VII Oberonia Lindl. \& Malaxis Sol. ex Sw. Dansk Botanisk Arkiv, 33, $1-91$.

Smith, J. J. (1908). Vorläufige Beschreibungen neuer papuanischer Orchideen. Bulletin du Département de l'Agriculture aux Indes Néerlandaises, 19, 1-39.

Smith, J. J. (1909). Die Orchideen von Niederländisch-Neu-Guinea. Nova Guinea: Résultats de l'Expédition Scientifique Nérlandaise à la Nouvelle Guinée en 1907-1909, 8(1), 1-148, pls.

Smith, J. J. (1912). Neue papuanische Pflanzen. I. Fedde Repertitorium Speciorum Novarum, Regni Vegetalis, 10, $486-488$.

Smith, J. J. (1915). Die Orchideen von Niederländisch-Neu-Guinea. Nova Guinea: Résultats de l'Expédition Scientifique Nérlandaise à la Nouvelle Guinée en 1912-1913, 12(3), 173-272.

Sokal, F. J. \& Rohlf, R. R. (1981). Biometry, the principles and practice of statistics in biological research second edition. New York: W. H. Freeman.

Stokes, D. J. (2008). Principles and practice of variable pressurelenvironmental scanning electron microscopy (VP-SEM). Southern Gate: John Wiley.

van Royen, P. (1979). The alpine flora of New Guinea, Vol. 2. Vaduz: J. Cramer.

WCSP (2020). World checklist of selected plant families. Facilitated by the Royal Botanic Gardens, Kew. Retrieved from http://wcsp.science.kew.org/ [Accessed 29/03/2020].

Wiley, E. O., Siegel-Causey, D., Brooks, D. R. \& Funk, V. A. (1991). The compleat cladist. A primer of phylogenetic procedures. The University of Kansas Museum of Natural History Special Publication, 19, 1-158.

Williams, L. O. (1938). Orchid studies, IV. The orchids of the Fiji Islands. Botanical Museum Leaflets, 5, $105-142$. 